\title{
北海道における歴史的建物の博 STUDY ON THE ACTUAL CONDITION 物館施設への保存活用の実態 OF THE PRESERVATION AND REUSE OF HISTORICAL BUILDINGS TO MUSEUMS IN HOKKAIDO
}

\author{
石本正明 - * $* 1$ 越野 武 - $* 2$ \\ 角 幸博— $* 3$ \\ キーワード \\ 歴史的建物, 博物館, 保存, 活用, 北海道 \\ Keywords : \\ Historical building, Museum, Preservation, Reuse, Hokkaido
}

\author{
Masaaki ISHIMOTO $-* 1$ \\ Yukihiro KADO - $* 3$ \\ Takeshi KOSHINO —— $* 2$
}

In this research, 85 museums based on preservation and reuse of historical buildings have comfirmed in Hokkaido, and these are classified into four types. The type of the most examples is the folk museum. Almost of facilities have established by public administration, and there are residents' requests for preservation of the historical building in many cases. The peculiarities and problems on the actual conditions of facility management and activities are different by four types of facilities. In type of the folk museum, there are many cases which have problems on the side of the management and the reusing of the historical building.
1.はじめに

歴史的建物は単に建物の文化財的な価値だけでなく、その建物に 刻まれたその地域の人々の生活や営みも貴重な歴史的資産と考える ことが出来る。それらを保存活用したり、あるいはかってあったも のを復元活用し、その持っている価值を高めることは「歴史を生か したまちづくり」の重要な一つである゙”。これらの活用方途の主 要な一つとして、博物館施設への保存活用が挙げられる ${ }^{\text {11。 }}$

北海道は「博物館王国」とも呼ばれ文い、その数は現在約 300 ほど あるといわれている主2!。これだけ多くの博物館施設が存在する背 景には、1968 (昭和43) 年の「北海道百年」に前後して、道内各地で 開基記念事業の一つとして郷土館や郷土資料館などの歴史博物館施 設が数多く設置されたこととも関係している妨。これらの中には、 地域の発展と共に歩んできた歴史的な建物を保存または復元し活用 する例も少なくない。また、北海道では1990年前後から、道庁の戦 略プロジェクト「歴史を生かすまちづくり」き31 を始めとして、文 化財や史跡、歴史的建造物等の歴史的資産をまちづくりに生かす試 みが各自治体で展開されている文6!。その中で「歴史的建造物の保 存・活用」と郷土館や資料館等の設置」の 2 つが、自治体の施設 整備と歴史的環境の整備を同時に取り組んでいけるまちづくり手法 の一つとして位置づけられつつある市)。歴史的建物の歴史性と施 設内容の歴史性を合わせもつ博物館施設への利活用は、歴史的建物 等の少ない自治体が多くを占める北海道の「歴史を生かしたまちづ くり」の展開を考える上で大きな意味をもっているといえよう。 北海道の歴史的建物の活用に関してはこれまでのところ、札幌市 や小樽市、函館市を対象に主として民間の再利用事例についての実
態調査 ${ }^{\left(21 . x^{81} \text {.文9) }\right.}$ が、また道内各市町村の小中学校旧校舎の活用実 態についての調查文10)がなされているが、博物館施設への活用事例 の実態は把握されていなかった。

そこで本報では、歴史を生かしたまちづくりにおける歴史的資産 の利活用の一つとして、郷土館・郷土資料館・郷土博物館・記念館 などと呼ばれる博物館施設を取り上げ、その歴史的建物活用事例の 全道的な把握とその実態調査により現状にみられる特徵や問題点を 把握整理し、今後の課題について若干の考察を加えた。

\section{2. 調查分析の方法}

\section{(1) 調查の対象}

本報で取り上げる対象は、以下の 3 点を目途にした。(1)歴史的建 物を博物館、鄉土資料館、記念館などの名称で利用し、一般公開し ているもの。(2)文化財建物（国、道、市町村指定）で一般公開をし ており、若干の歴史資料展示機能も有するもの。(3)活用建物の建設 年次が、およそ昭和 20 年代頃までのもの。なお、博物館法による定 義では、美術館や科学館、水族館、動物園も博物館に含まれるが、 本報では歴史博物館文 ${ }^{2}$ およびこれに類する施設を対象とするので これらの事例き4)はいずれも除外した。また、建設当初から博物館 機能を有する施設注 5 も除いた。

\section{(2) 調查概要}

道内各市町村の事例把握に先立ち、道内の博物館のガイドブッ ク文11.女121，および北海道公立小中学校旧校舎の再利用調査結果文 10 ， をもとに対象施設と思われる事例の予備的把握をした。その上で調 查はまず、北海道212市町村を対象に電話による聞き取りを行い、 52

\footnotetext{
*1 Research Assoc., Graduate School of Eng., Hokkaido Univ.

*2 Prof., Graduate School of Eng., Hokkaido Univ., Dr. Eng.

*3 Assoc. Prof., Graduate School of Eng., Hokkaido Univ., Dr. Eng.
} 
市町村で85事例を確認した。調查は1996年10月上旬〜11月下旬、主 に各市町村の教育委員会担当課 ${ }^{\text {(6) }}$ への問い合わせにより行った ${ }^{\text {in }}$ 。

次に、それらを管轄する各市町村の教育委員会および所管行政機 関や企業、または直接該当施設に、各事例毎のアンケート調查を行 つた。調査は1996年11月29日〜1997年1月9日で、郵送により行った。 調查内容は、大きくは以下の 5 つの事項である。(1)施設および活用 建物の概要 (規模、建築年、構造階数、用途等)、(2)活用に至った経 緯（関連事業、設置の目的意義等）、(3)施設の運営・活動状況（職 員配置、開館および入館者状況、活動内容等)、(4)施設設置時の建物 変更および利用上の建築的問題点、(5)施設建物に対する評価·期待。

調查の結果、42市町村66事例について回答が得られた ${ }^{\text {(2) }}$ 。調查 対象および回答事例の一覧は、表1に示すとおりである。前述の参 考文献文11)、文12) と今回の調查結果を合わせると芒9)、道内の歴史博 物館施設の約 3 割が歴史的建物を活用したものである。

\section{(3) 対象事例の分類型}

博物館の分類は様々に試みられているが文 ${ }^{5 !}$ 、本報では展示等の 施設内容と施設名称から、[S] 郷土資料館型（展示テーマが地域の 歴史一般であるもの)、[C] 地域専門型（地域の特定分野について 語るもの）、 [K] 記念館型（特定の歴史的人物や事象を遺産として 残すもの)、[B] 文化財型（施設名を文化財名など旧建物名称で表 すもの)、の4つの施設型に分け（表1参照）、各分類型毎の現状と その特徵や問題点等を探った。

\section{3. 調查把握事例の全体的概要 (1) 施設設置の䞻勢}

北海道の博物館施設全体としては1980年代前半に設置数がピーク となっているが、歴史的建物を活用した施設视10)はこれより少し遅 れて 80 年代の後半にピークをむかえている（表2）。記念館型や文 化財型の施設は1950年代から現在まで広く見受けられるのに対し、 郷土資料館型は60年代後半から、また地域専門型では 70 年代後半か ら設置が始まっている。これらのほとんどは市町村自治体により設 置開設されており、民間所管の施設はわずか 8 件と少ない。この他 に、かって私設の資料館や郷土館であったものが自治体に移管され た例も2件みられる（表1中の事例53、63）。

アンケート調査の回答 66 事例について、旧建物の所有関係をみる と、現在自治体で所有管理している 60 事例の6割（37例）は民間所 有の建物であった。特に、文化財型（14事例中12例）や記念館型 $(9$ 事例中7例）に多いが、郷土資料館型でも29事例中 13 例とほほ半数 を占める。これらの建物は買取りまたは寄贈により取得されている が、概ねどの施設型でも寄贈の方が多い。個人や企業が貴重な建物 を後世に残したいという積極的な行為が、こうした博物館施設づく りの重要な支えにもなっていることがうかがえる。

また、新たな博物館等の建設や開設に伴って、旧施設を取り壊す ことなくその一部として活用したり、別の博物館施設として存続さ

表2 調查対象施設の設置年次別事例数

\begin{tabular}{|c|c|c|c|c|c|c|c|c|c|}
\hline & & & & & $980-84$ & & & & 計 \\
\hline 鄉土資料館型 & $E$ & $2(2)$ & $6(5)$ & $5(3)$ & $8(7)$ & $8(8)$ & $6(3)$ & $2(1)$ & $37(29)$ \\
\hline 地域専門型 & & & & $2(2)$ & $3(2)$ & $3(2)$ & 2(2) & $2(2)$ & $2(11$ \\
\hline 記念館型 & $2(1)$ & $2(2)$ & $1(1)$ & $1(1)$ & $1(1)$ & 5 & (1) & $2(1)$ & 17( \\
\hline 文化財型 & $3(2)$ & & $2(2$ & 21 & & $6(4)$ & $1(1)$ & $2(2)$ & 1991 \\
\hline 誥 & $5(3)$ & $4(4)$ & $9(8)$ & $10(7)$ & $15(12)$ & $22(18)$ & $12(8)$ & 8 & $-85(66)$ \\
\hline 内の博物馆 & 34 & $\frac{7171}{26}$ & 34 & 52 & 79 & $\frac{2410}{36}$ & $\frac{12(0)}{14}$ & $\frac{8(0)}{-}$ & $\frac{100100}{275}$ \\
\hline
\end{tabular}

表1 調查対象施設一筧

\begin{tabular}{|c|c|c|c|c|c|c|c|c|c|c|c|c|c|}
\hline 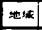 & 1) No. & 市町村 & 施設名（旧建物名称、建設年） & 阙管年 & 2) & \begin{tabular}{|l|l|}
$3)$ & $4)$ \\
\end{tabular} & 里 & 1) No. & 市町村 & 施設名（旧建物名称、建設年) & 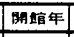 & 2) & 4) \\
\hline \multirow{18}{*}{ 石 } & $* 1$ & 札幌市 & エドウイン・ダン記念馆(真駒内種音場事務所,1887) & 1967 & 遷 & $\mathrm{K}$ & \multirow{9}{*}{ 空知 } & * 41 & 滰川市 & 䔔川市郷土答分官·華月館(三浦的，1915) & 1980 & 自 & \\
\hline & * 2 & 札垷市 & 札幌市資料館(札幌控訴院,1926) & 1973 & 較: & $\Delta \mathrm{s}$ & & 42 & 滰川市 & 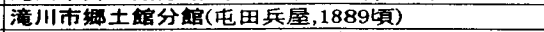 & 1982 & 自 & $\mathrm{s}$ \\
\hline & $* 3$ & 札靦市 & 札愰市水道硙念馆(灌岩山第一浄水場, 1937) & 1977 & & $\triangle \mathrm{C}$ & & * 43 & 夕張市 & 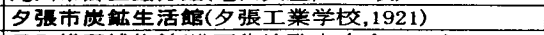 & 1981 & & $\mathrm{C}$ \\
\hline & $* 4$ & 札㨪市 & 札愢市冬のスポーツ博物馆(NHK札幌放送局，1928） & 1980 & & $\triangle \mathrm{C}$ & & * 44 & 月形町 & 月形樺戸博物的(㯜戸集治監本庁含, 1886) & 1996 & & $B$ \\
\hline & $* \quad 5$ & 札幌市 & 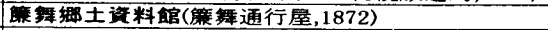 & 1985 & 自 & $\mathrm{s}$ & & *45 & 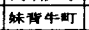 & 妹背牛町㛛土亚(妹背牛村役場, 1931) & 1987 & & s \\
\hline & $* 6$ & 札幌市 & 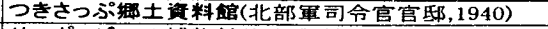 & 1985 & 選 & $\mathrm{s}$ & & 46 & 新+津川 & 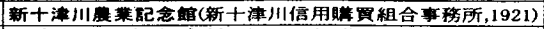 & 1986 & & \\
\hline & \multirow{2}{*}{$\begin{array}{ll}* \quad 7 \\
& 8 \\
\end{array}$} & 札幌市 & サッポロビール十物館(札幌製梼会社工場, 1890) & 1987 & 選 & $\triangle C$ & & 47 & 雨竟町 & 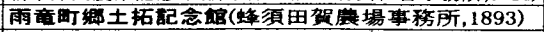 & 1973 & & \\
\hline & & 札愰市 & 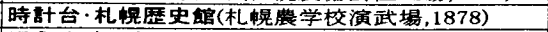 & 1978 & 国 & s & & 48 & 栗山町 & 泉配念館(泉邸, 1898) & 1979 & & \\
\hline & 9 & 札幌市 & 揸永山武四郎败(1880頃) & 1987 & 道 & $B$ & & 49 & 害山町 & 北の苇記念秢(小林酒造事務所, 1954) & 1995 & & \\
\hline & 10 & 札幙市 & 新零似屯田中隊本部(1886) & 1974 & 自 & $\mathrm{B}$ & & 50 & 旭川市 & 北镇記念宿(農林省北見種馬場，1937） & 1964 & & K \\
\hline & 11 & 札㹸市 & 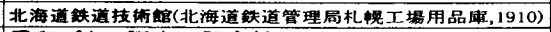 & 1987 & & $\bar{C}$ & & $* 51$ & \pm 別市 & 士別市公会堂展示官(士別公会堂,1915) & 1989 & 自 & \\
\hline & 12 & 札垷市 & 焉印バター诞生の記念馆(宇納牧場製酪所,1925) & 1981 & & C & & * 52 & 当晽町 & 当晽町艮土筫料馆(当标町役場, 1926 & 1982 & & \\
\hline & 13 & 札幌市 & 宫部金垔妃念舵(札愢農学校動植物教室東翼,1901) & 1991 & 国 & $\mathrm{K}$ & & * 53 & 別町 & 安足間開颃買料领(小山家住宅, 1907) & 1971 & & $\mathrm{~s}$ \\
\hline & 14 & 江別市 & 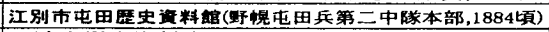 & 1995 & 道 & $\mathrm{s}$ & & $* 54$ & 別町 & 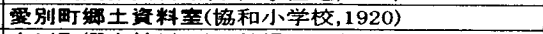 & 1990 & & \\
\hline & 15 & 石狩市 & 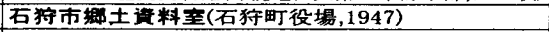 & 1994 & & $\mathrm{~s}$ & & $* 55$ & 東川町 & 東川町郎土館(東川开厂役場,1949) & 1982 & & $\mathrm{~s}$ \\
\hline & \begin{tabular}{|l|l|}
$* 16$ \\
\end{tabular} & 北広盘市 & 国史跡旧息松野䎠所(1873) & 1991 & 国 & B & & * 56 & 上要息野 & 上富良野町哏土館(上富良野町役場,1919) & 1979 & & \\
\hline & \begin{tabular}{|l|l|}
$*$ & 17 \\
\end{tabular} & 当別町 & 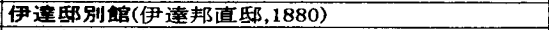 & 1983 & 自 & $\mathrm{K}$ & \multirow{6}{*}{$\begin{array}{l}\text { 留 } \\
\text { 明 }\end{array}$} & * 57 & 小平町 & 重要文化財·旧花田家番屡(1904頃) & 1976 & 国 & $B$ \\
\hline & $* 18$ & 浜益村 & 浜益村郎土資料领(白鳥家番屋,1899) & 1971 & 自 & s & & $* 58$ & 苫前町 & 苫前町哏土资料绾(苫前町役場，1928) & 1984 & & $\mathrm{~s}$ \\
\hline \multirow{8}{*}{$\begin{array}{l}\text { 渡 } \\
\text { 島 }\end{array}$} & $* 19$ & 函鲩市 & 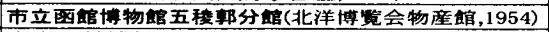 & 1955 & & $\mathrm{~K}$ & & $* 59$ & 羽幌町 & 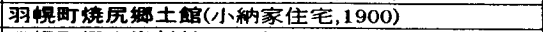 & 1978 & 道 & \\
\hline & * 20 & 画鲩市 & 市立面館博物官䐚土資料馆(金森洋物店, 1880) & 1969 & 道 & O $1 \mathrm{~s}$ & & $* 60$ & 羽䭪町 & 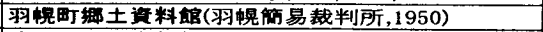 & 1989 & & \\
\hline & *21 & 函舵市 & 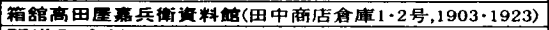 & 1988 & 歴 & $\mathrm{K}$ & & \begin{tabular}{|l|}
$* 61$ \\
\end{tabular} & 遠別町 & 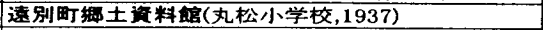 & 1984 & & \\
\hline & $* 22$ & 函馆市 & 開港記念官(イギリス領事館,1913) & 1992 & 自 & $\triangle \mathrm{K}$ & & *62 & 天塩町 & 天塭川歴史買料秢(天塩町役場,1951) & 1989 & & \\
\hline & * 23 & 函鲩市 & 函馆市文学馆(第一銀行函館支店,1921) & 1993 & 歴 & C & \multirow{3}{*}{$\begin{array}{l}\text { 宗 } \\
\text { 谷 }\end{array}$} & $* 63$ & 豊亩町 & 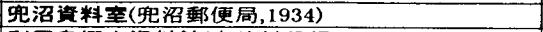 & 1992 & & $s$ \\
\hline & $* 24$ & 函㴶市 & 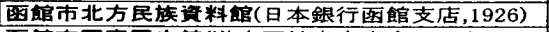 & 1993 & & C & & * 64 & 利兵画土 & 利层暍䐚土資料管(鬼脇村役場, 1913) & 1973 & & \\
\hline & $* 25$ & 西鲩市 & 要馆市写真厢史館(道庁函館支庁庁舎, 1909) & 1995 & 道 & C & & 65 & 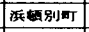 & 浜頓別町编土筫料绾(浜頓別町役場，1921） & 1975 & & $\mathrm{~s}$ \\
\hline & * 26 & 上磯町 & 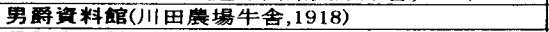 & 1978 & & $\mathrm{~K}$ & \multirow{4}{*}{ 走 } & * 66 & 北見市 & ピアソン記念館(ピアソン邸,1914) & 1966 & 自 & $\mathrm{K}$ \\
\hline \multirow{3}{*}{ 桧 } & * 27 & 江差町 & 重要文化財-旧中村家住宅(1889頃) & 1972 & 国 & B & & \begin{tabular}{|l|l|}
$* 67$ \\
\end{tabular} & 北見市 & 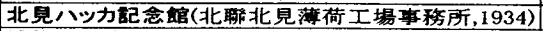 & 1986 & 自 & \\
\hline & $* 28$ & 江差町 & 旧関川家別荻(明治初期) & 1987 & 自 & $\triangle \mathrm{B}$ & & $* 68$ & 網走市 & 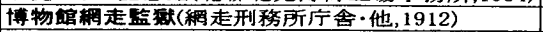 & 1989 & & O $\mathrm{C}$ \\
\hline & 29 & 江差町 & 旧横山夷(1893) & 1964 & 道 & B & & $* 69$ & 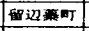 & 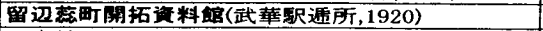 & 1971 & & \\
\hline & * 30 & 小模市 & 小模市権御殿(田中家住宅,1897) & 1959 & 道 & $B$ & new & * 70 & 伊達市 & 迎實會(伊達邸，1892) & 1964 & 自 & $\mathrm{B}$ \\
\hline & \begin{tabular}{ll|}
$* 31$ \\
\end{tabular} & 小榑市 & 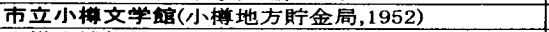 & 1978 & & O) & \multirow{4}{*}{ 旦 } & * 71 & 觧内町 & 龍霣用(1908) & 1972 & & $\mathrm{~B}$ \\
\hline & $* 32$ & 小橝市 & 小搭市博物食(小楢倉庫(株)倉庫,1890) & 1985 & 市化 & \begin{tabular}{l|l} 
& $\mathrm{s}$ \\
\end{tabular} & & \begin{tabular}{ll|l}
$* 72$ \\
\end{tabular} & 逋河町 & 赤心社記念館(赤心社(株)荻伏出張 & 1974 & & $\mathrm{~K}$ \\
\hline & $* 33$ & 小權市 & 旧日本董船(株)小俩支店(1906) & 1987 & 国 & $\mathrm{B}$ & & \begin{tabular}{|l|l|}
$* 73$ \\
\end{tabular} & 浦河町 & 浦河町鄉土博物馆(浦河東小学校,1957) & 1978 & & $\mathrm{O} / \mathrm{s}$ \\
\hline & $* 34 \mid$ & 小榙市 & 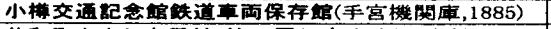 & 1996 & 記 & C & & * 74 & 様似町 & 旧竹内土家土藏(1907) & 1983 & & $\mathrm{~B}$ \\
\hline & $* 35$ & 共和町 & 共和町かかし古里官·第二展示宰(㹸似小学校,1933) & 1997 & & $\mathrm{~s}$ & \multirow{5}{*}{ 勝 } & * 75 & 士煶町 & 美瀑の家(洞田邱,1916) & 1988 & & $\mathrm{~B}$ \\
\hline & $* 36$ & 余市町 & 旧下ヨイチ喧上家 $(1781-88)$ & 1980 & 国 & B & & $* 76$ & 忠類村 & 国鉄広尾線铁道記念館（国鉄広尾線忠類駅,1930) & 1988 & & $\mathrm{~K}$ \\
\hline & * 37 S & 余市町 & 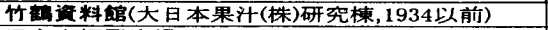 & 1986 & & $\bar{K}$ & & * 77 & 㑒別町 & 新田の森配念馆(新田べ二ヤ製造所合車,1919) & 1996 & & $\mathrm{~K}$ \\
\hline & \begin{tabular}{|c|}
$* 38$ \\
$* 38$
\end{tabular} & 余市町 & 旧余市楅原漁唔(1877-1917) & 1995 & 国 & $\mathrm{B}$ & & * 78 & 足霖町 & 足套町郎土犋料館(足㟢村役埸,1934) & 1986 & & $\mathrm{~s}$ \\
\hline & \multirow{2}{*}{$\begin{array}{r}30 \\
* 39 \\
440\end{array}$} & 泊村 & 泊村鄉土馆(川1村鹿次郎鲢番屋,1894) & 1980 & & s & & 79 & 中札闪村 & 中札内開拓記念館(浜野家住宅,大正末) & 1992 & & s \\
\hline & & 岛牧村 & 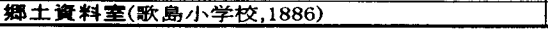 & 1990 & & $\mathbf{S}$ & & $* 80$ & 釧路市 & 米町ふる⿸尸と館(渡辺邸,1900) & 1989 & & \\
\hline & & & 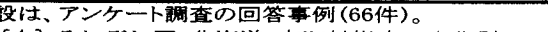 & & & & & $* 81$ & 釧路市 & 港文馆(釗路新閒社社屋, 1908) & 1993 & & K \\
\hline & & & & & & & & $* 82$ & 榇茶町 & 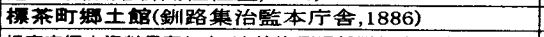 & 1969 & 自 & \\
\hline & & & & & & & & * $83 \mid$ & 根室市 & 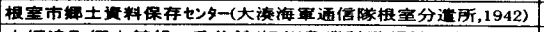 & 1990 & & s \\
\hline & r & & IDI & & & & & \begin{tabular}{|l|l|}
$* 84$ \\
\end{tabular} & 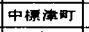 & 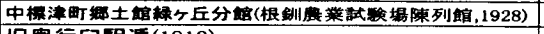 & 1983 & & \\
\hline & & & & & & & & 85 & 别海町 & 䢐奥行鼠配(1910) & 985 & 道 & \\
\hline
\end{tabular}




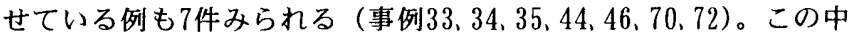
には文化財指定以外の建物が4例ある。郷士の貴重な財産として再 び活用していくことの意義は大きいといえよう。

\section{(2) 活用建物の種類}

活用建物の種類は施設分類型によってその傾向に違いもみられる (表3)。地域専門型や記念館、文化財型の施設が裁判所や刑務所関 係、郵便局、軍施設など特殊な建物に偏りがみられるのに対し、郷 土資料館型はこの他に旧役場庁舎や学校校舎など活用建物の種類に 幅がある。住宅系の建物 ${ }^{11}{ }^{11}$ の活用事例も多く（24件）みられるが、 そのほとんどは拫土資料館型と文化財型の施設への活用でほぼ同数 程度となっている。また記念館型には、かって民間の業務・商業施 設であった建物を活用している例が他の施設型に比べ多い。

北海道の多くの自治体ではこれまでに、戦前期頃までに建てられ た役場庁舎の建替をしているが、今回の調査では昭和 20 年代頃まで に建てられた庁舎を活用している事例は10件ほどであった。また、 かっての学校校舎の博物館施設への活用事例も意外に少なく、調査 で確認されたのは7例であった。役場庁舎は全てが、また学校校舎 も7事例中5例が郷土資料館型の施設として再生されている。

\section{表3 活用された建物(建設当初)の種類別事例数}

\begin{tabular}{|c|c|c|c|c|c|c|c|c|c|}
\hline \multirow{2}{*}{ 施設分類型 } & \multicolumn{5}{|c|}{ 公的な施設 } & \multicolumn{2}{|c|}{ 民間施設 } & \multirow{2}{*}{ 住居系5) } & \multirow{2}{*}{ 計 } \\
\hline & 役場庁告 & 学校校舎 & 鄴務系1) & その他 ${ }^{2 !} !$ & (小計) & 商業駇主| & その他 & & \\
\hline 郷土資料館型 & $10(8)$ & $5(4)$ & $3(3)$ & $6(4)$ & $24(19)$ & $2(1)$ & $1(1)$ & $10(8)$ & $37(29)$ \\
\hline 地域専門型 & - & $1(1)$ & $3(3)$ & $4(3)$ & $8(7)$ & $2(2)$ & $2(1)$ & - & $12(10)$ \\
\hline 記念館型 & - & $1(0)$ & $2(2)$ & $3(2)$ & $6(4)$ & $6(4)$ & $3(3)$ & $2(2)$ & $17(13)$ \\
\hline 文化財型 & - & - & - & $3(2)$ & $3(2)$ & 1 (1) & $3(3)$ & $12(8)$ & $19(14)$ \\
\hline 計 & $10(8)$ & $7(5)$ & $8(8)$ & $16(11) !$ & $41(32)$ & $11(8)$ & $9(8)$ & $24(18)$ & $85(66)$ \\
\hline
\end{tabular}

\section{（3）博物館法および文化財等の指定}

博物館法で定める施設には、博物館登録施設と相当施設があり、 これらと同類の事業を行うその他の施設は博物館類似施設と呼ばれ

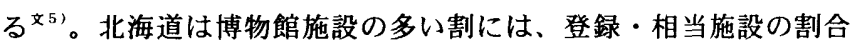
は低( ${ }^{ \pm 12)}$ 。調查対象事例でみても、登録博物館は5 件、博物館相 当施設は9件と少ない(表1参照)。

一方、対象事例85件のうち33施設で、活用建物が国・北海道・市 町村指定の文化財あるいは自治体の歴史的建造物等の指定を受けて いる (表1参照)。郷土資料館型施設でも、約 $1 / 3$ は文化財等の歴史 的建造物として指定を受けている建物が活用されている。

\section{4. 施設設置の背景と施設建物への期待}

以下の章では、調查回答事例66施設について実態を把握分析する。

\section{(1)事業的な位置づけと補助金制度の適用}

施設設置が自治体または企業の事業に位置づけられている例は21 件で、回答事例の約 $2 / 3$ は独自の事業として実施されている。関連 事業の中では、やはり自治体の開基記念事業が最も多い（12件）。 この他に、企業や都市事業の創業等を記念してのものが4例（表1の 事例3，7，30，81）、環境整備事業の一畩として位置づけられている ものが5例（事例 $16 、 31,35 、 43 、 80 ）$ みられる。一方、自治体の総合 計画に具体的に位置づけられている例は少なく、今回の調査では僅 かに2例（事例35、51）が確認されたにとどまる。

施設整備に際して国や道からの補助金を受けている事例は約 $1 / 3$ (21件) で、独自財源による設置事例の方が多い。主なものは、文化
財指定建物の保存修復に関する事業（8例）と北海道市町村振興補 助金（5例）で、後者では文化財無指定の郷土資料館型施設が中心 となっている。補助金制度適用事例の8割は設置開設年が 1980 年以 降のもの (17件) で、特に 80 年代後半が多い (12件)。わが国では 19 80 年代後半から国の各省庁によるまちづくりに関する補助事業制度 が多数設けられているが、これらの補助制度の活用事例は文化財保 存関連以外では3例（事例 $34 、 59,80 ）$ 目3) と少ない。

\section{(2) 施設設置の目的・意義および住民の要望}

施設の設置者または管理者に対し、施設設置の目的意義や建物の 保存活用の意義について專ねた（自由回答）結果、内容は大きくは 以下の4つに整理される。(1)資料の保存·展示による歴史の伝承 $(23$ 例)、(2)住民の学習に供する、文化意識の向上 (16例)、(3)貴重な建 物の保存·伝承 (32例)、(4)観光資源として地域の発展に寄与 (7例)。 施設内容の歷史的な役割と共に、貴重な地域遺産として歴史的建物 を後生に残すことの指摘が多い。対象が歴史的建物を生かした博物 館施設であることの意味が素直に表れているといえよう。

一方、地域住民からの要望は、施設設置の要望（17件）に比べ、 建物保存に関する要望の方が多く(35件) 回答事例の半数を超える (表4)。この傾向は文化財型施設で強いが、郷土資料館型施設でも 建物保存の要望が文化財型に次いで多くみられるのが注目される。 建物保存と施設設置の要望を併せると、全事例の7割の施設で住民 からの要望がみられる。記念館型 (54\%) 以外の型はいずれも70\%を超 え、特に郷土資料館型では29例中 22 件と全体の $3 / 4$ に達する。住民 要望の有無を施設設置年との関係からみてみると(表4)、設置数が ピークにさしかかる1980年前後を境に住民の要望傾向に変化がみら れる。1980年以前では要望のあった事例は半数程度であるのに対し、 80 年以降は7割を超えており、90年代の最近のものでは 14 例中 11 件 （79\%）となっている。歴史的建物を生かした博物館施設づくりに 対する住民の働きかけは着実に多くなっていることがわかる。

表4 施設の設置および活用建物の保存に対する住民の要望(指摘件数)

\begin{tabular}{|c|c|c|c|c|c|c|c|c|c|}
\hline 設置年 & |郷土資料館型 & 地域専阴开 & 記念館型 & 文化財型 & 計 & 0 & $\square$ & 10 & 要望あり \\
\hline 1970以前 & 00 & & पOx & $x x$ & 7 & 3 & 1 & 0 & $3(43 \%)$ \\
\hline 1970-79 & $\begin{array}{l}0000 \times \\
0 \times x\end{array}$ & $x x$ & $0 x$ & $O x$ & 14 & 5 & 0 & 2 & $7(50 \%)$ \\
\hline $1980-84$ & ${ }_{x \times}^{00000}$ & 00 & $x$ & 000 & 13 & 9 & 1 & 0 & $10(77 \%)$ \\
\hline $1985-89$ & $\begin{array}{l}\text { OOODQ } \\
0 \times x\end{array}$ & $0 x$ & $00 \times x$ & 000 & 18 & 8 & 5 & 1 & $14(78 \%)$ \\
\hline $1990-$ & $00 \times 0$ & Dलवि & $00 x$ & $00 x$ & 14 & 4 & 4 & 3 & $11(79 \%)$ \\
\hline 計 & 29 & 10 & 13 & 14 & 66 & 29 & 11 & 6 & $46(70 \%): 2$ \\
\hline 0 & 13 & 3 & 5 & 8 & 29 & \multirow{4}{*}{\multicolumn{4}{|c|}{ 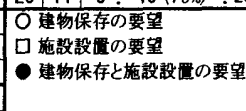 }} \\
\hline प & 6 & 3 & $\frac{\pi}{1}$ & 1 & 11 & & & & \\
\hline 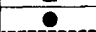 & 3 & 1 & 1 & 1 & 6 & & & & \\
\hline 要望あり & $22(76 \%)$ & $7(70 \%)$ & $7(54 \%)$ & $10(71 \%)$ & $46(70 \%)$ & & & & \\
\hline$x$ & 7 & -3 & 6 & 4 & 20 & $\times$ & 要望 & T T T & \\
\hline
\end{tabular}

\section{(3) 施設建物への期待}

施設建物に寄せられる「地域のシンボル性」と「建物の歴史的役 割」について、管理者の認識を通じて把握した ${ }^{\text {14) }}{ }^{4)}$ 。その結果、 47 施設でシンボル性または歴史的役割のいずれかが指摘された。文化 財型 (100\%) や地域専門型 (80\%) の施設に比べ、記念館型 (58\%) 郷土 資料館型 $(64 \%)$ では指摘が低い。いずれの型でも、施設のシンボル 性よりは建物の歴史的役割の方が強く認識されているが、文化財型 （ジボ $164 \%$ 、歴史 $86 \%$ ）や地域専門型 (同50\%、70\%）施設に比べ、 郷土資料館型 (同 $25 \%$ ，54\%）や記念館型施設 (同 $25 \%$ ５0\%）ではシン ボル性に対する期待についての認識はかなり低い状況にある。 


\section{5. 施設の運営状況と事業・活動 5-1 施設規模と運営状況}

(1)施設規模（延床面積）:地域専門型施設は平均に規模が大きく その半数は $1000 \mathrm{~m}^{2}$ 以上であるが、他の施設型はいずれも $500 \mathrm{~m}^{2}$ 未満 の施設が6割以上を占め、平均規模は500 m前後と小さい（表5)。

(2)職員数 : 博物館の職員数は一般的に施設の規模と比例している ことが把握されている文6)。今回の調查でも、平均規模の大きい地 域専門型と他の施設型では、職員数にも大きな開きがある (表6)。 非常勤も含め常駐職員なしの施設が全体で6例、また1人の施設が 23 例みられるが、このうち22例は地域専門型以外の施設である。さら に常勤職員数では1人が15例、いない施設が17例もある。特に郷土 資料館型に常勤職員のいない施設が多く、29事例中 12 例之全体の 4 割を超える。また常勤職員のいる施設でも、施設の管理や受付の空 口対応の職員である場合が多い。

学芸員等の専門的職員については、今回の調査では正確な実態が 把握できなかったが、職員構成の回答結果から判断すると、学芸員 等のいる施設は 10 事例ほど確認され、その半数は地域専門型の施設 である。一方、郷土史研究会 (事例52) や生涯学習アドバイザー (事 例45）に委嘱している例が2件ほどみられた。事例としては僅かだ が、専門職員の配置が難しい郷土資料館などの運営のあり方を考え る上で示唆的な事例といえよう。

(3)年間開館日数 : 地域専門型や記念館型、文化財型施設の多くは ほぼ年間通じて開館しており、特に地域専門型施設では 10 事例中 9 例が250日以上である。これに対し郷土資料館型では年間250日未満 の施設が約 6 割を占め $(29$ 事例中 17 例)、さらに 100 日未満も6例み られる(表7)。これらのほとんどは冬期間閉館している施設で、 特に道北や道東地域の施設に多い。

(4)入館者数 : 開館日数が平均に長い地域専門型施設は他の施設型 に比べ年間入館者数も多く、全ての施設が1万人以上である。郷土 資料館型は年間 $5 千$ 千未満の施設が全体の 6 割を超え、千人未満の施

表5 施設の平均規模(建築延べ床面積)および規模別事例数

\begin{tabular}{|c|c|c|c|c|c|c|c|c|}
\hline 施設分類型 & 平均規模 & $100 \mathrm{~m}^{2}$ 未满 & $100-200$ & $200-500$ & $500-1000$ & $1000 \mathrm{~m}^{2}$ 以上 & 不明 & 計 \\
\hline 㦄土資料馆型 & $538 \mathrm{~m}^{2}$ & 1 & 4 & 13 & 7 & 3 & 1 & 29 \\
\hline 地域専門型 & $1273 \mathrm{~m}^{2}$ & - & - & 2 & 3 & 5 & - & 10 \\
\hline 記念館型 & $628 \mathrm{~m}^{2}$ & 3 & 4 & 3 & 2 & 1 & - & 13 \\
\hline 文化財型 & $453 \mathrm{~m}^{2}$ & 1 & 2 & 5 & 5 & - & 1 & 14 \\
\hline 計 & $654 \mathrm{~m}^{2}$ & 5 & 10 & 23 & 17 & 9 & 2 & 66 \\
\hline
\end{tabular}

表 6 施設の平均職買数および人員数別事例数

\begin{tabular}{|c|c|c|c|c|c|c|c|c|}
\hline 施設分類型 & 平均人員 & $\begin{array}{l}\text { 無し } \\
\end{array}$ & 1人 & 2-4人 & 5-9人 & 10人以上 & 不明 & 計 \\
\hline 郷士資料館型 & $2.5 人$ & $3(12)$ & $13(6)$ & $6(6)$ & $6(4)$ & - & 1 & 29 \\
\hline 地域専門型 & 12.6 人 & - & 1(1) & $3(3)$ & $3(3)$ & $3(3)$ & - & 10 \\
\hline 記念館型 & 2.01 & $2(4)$ & $5(3)$ & $5(6)$ & $1(0)$ & - & - & 13 \\
\hline 文化財型 & $2.7 \widehat{\Lambda}$ & $1(1)$ & $4(5)$ & $5(6)$ & $2(0)$ & - & 2 & 14 \\
\hline 計 & 4.0人 & $6(17)$ & $23(15)$ & $19(21)$ & $12(7)$ & $3(3)$ & 3 & 66 \\
\hline
\end{tabular}

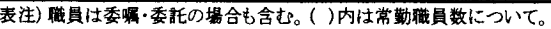

表7 施設の平均年間開馆日数および日数別事例数

\begin{tabular}{|c|c|c|c|c|c|c|c|c|}
\hline 施設分類型 & 平均日数 & 150日末满 & $150-250$ & $250-350$ & 350 日以上 & 不明 & 計 & 4 为明的 \\
\hline 郷士犋料館型 & 194日 & $11(6)$ & 6 & $\overline{9}$ & $T$ & 2 & 29 & $\overline{13}$ \\
\hline 地域専門型 & $327 日$ & - & 1 & 3 & 6 & - & 10 & $\frac{10}{1}$ \\
\hline 記念館型 & 2566 & $1(1)$ & 4 & 6 & 2 & - & 13 & 5 \\
\hline 文化財型 & 2466 & $2(1)$ & 3 & 8 & - & 1 & 14 & 3 \\
\hline 部 & 239日 & $14(8)$ & 14 & 26 & $\overline{9}$ & 3 & 66 & 22 \\
\hline
\end{tabular}

表8 施設の一日平均入館者数および人数別事例数

\begin{tabular}{|c|c|c|c|c|c|c|c|c|}
\hline 施設分類型 & 平均人数 & 10 人未满 & $10-50$ 人 & $50-100$ 人 & $100-500$ 人 & 500 人以上 & 不明 & 計 \\
\hline 榔士凟料館型 & 44 人 & 12 & 8 & 4 & 2 & - & 3 & 29 \\
\hline 地域専門型 & 340 人 & - & - & 6 & 1 & 3 & - & 10 \\
\hline 記念館型 & $87 \curlywedge$ & 3 & 5 & 2 & 3 & - & - & 13 \\
\hline 文化財型 & 172 人 & - & 6 & - & 5 & 1 & 2 & 14 \\
\hline 計 & $127 \curlywedge$ & 15 & 19 & 12 & 11 & 4 & 5 & 66 \\
\hline
\end{tabular}

設も3割近くみられる。これらのほとんどは冬期閉館の施設である。

一日平均入館者数でみると (表8)、郷土資料館型の約 7 割の施設 は 50 人未満で、一日の入館者が 10 人に満たない施設が 29 例中 12 例も ある。型別の平均值でみても、記念館型の 87 人、文化財型の 172 人 に比べ、郷土資料館型は 44 人とかなり少ない。こうした施設利用者 の少なさが、冬期閉館施設の多さにも関係していると考えられる。

\section{5-2 施設の事業・活動}

\section{（1）展示活動（表9参照）}

回答を得た 66 事例中、2施設（事例54.70）以外は、全て常設展示 がなされている。しかし、事業活動が常設展示のみの施設が 66 件中 37件と半数を超えている。こうした実態には、学芸員等の不在や規 模の小さな施設が多いことも背景の一つにあると推察される。

これまでに特別展を実施したことのある施設は全体の約 $1 / 4$ 程度 で、地域専門型と郷土資料館型で実施率がやや多い傾向にある。博 物館法に基づく登録博物館 5 事例のうち4施設（事例 $20 、 31,32 、 73$ ) で特別展が実施されているが、博物館相当施設では 9 事例中 3 件 (事例 22 、57,64）と少ない。一方、博物館法の登録・相当施設以外にも 10 施 設で実施されており、うち6つは郷土資料館型の施設である (事例 45 、 $51,56 、 58,61,62)$ 。厳しい運営体制の中でこうした郷土資料館施設 が特別展示等の実績経験をもつことの意義は大きいといえよう。

表 9 施設活動の実施状況

\begin{tabular}{|c|c|c|c|c|c|}
\hline 施設分類型 & 特別展 & 普及活動 & 出版物刊行 & 常設展示の子 & 事例総数 \\
\hline 鄉土资料館型 & $9(31)$ & $7(24)$ & $7(24)$ & $16(55)$ & 29 \\
\hline 地域専門型 & $3(30)$ & $5(50)$ & $1(10)$ & $4(40)$ & 10 \\
\hline 記念館型 & $2(15)$ & $4(31)$ & $1(8)$ & $9(69)$ & 13 \\
\hline 文化財型 & $2(14)$ & $5(36)$ & $0(-)$ & $8(67)$ & 14 \\
\hline 計 & $17(26)$ & $21(32)$ & $9(14)$ & $37(56)$ & 66 \\
\hline
\end{tabular}

（2）普及活動および出版物の刊行（表 9 参照）

体験学習や見学会等の普及活動を実施している施設は、66事例中 21件であった。やはり地城専門型で奏施率が高く（半数の施設）、 楖土資料館型は29事例中7件と最も低い状況にある。66事例中、常 設展・特別展のほかに普及活動も行っている施設は全体で10件程度 であった。館内での解説活動に関しては、今回の調査では全体の実 態は把握できなかったが、指定文化財施設の中にはく来館者に対し 施設等の詳細な説明を行い好評を得ている>という管理者の意見が みられた（事例5、28、27など）。施設職員の配置状況から察すると、 こうした解説活動が行える施設はそれほど多くはないと思われる。 施設活動に関連する出版物については、実施状況はさらに低い。 これまでに何らかの出版物を刊行したことのある施設は、9件（事 例 $6 、 8 、 19 、 32,51,56 、 68 ， 73 ， 82 ）$ と少ないが、うち7つは拫土資料館 型の施設である。これらの事例で学芸員のいる施設は半数以下であ るが、中には施設活動をサポートする市民活動団体によって定期的 な刊行が続けられている例 ${ }^{(15)}$ もみられ、今後の参考事例として注 目される。

施設内での普及活動には研修室や学習室等の整備状況も関わって くる。今回の調査では45施設のパンフレットおよび13施設の建物平 面図が収集できた。これらの資料から研修・学習室等の整備状況を みると、7施設（事例 $22 、 24,31,45,52 、 58,64 ）$ で設置がみられる。 （3）他施設や学校とのつながり（表10参照）

回答事例の $2 / 3$ 施設で、地域内外の他の博物館施設等と何らか 
のつながりをもっている。ただ内容的には情報の収集や交換がほと んどで、これらも含め連携を行っている事例は全体の約1割と少な い。他の施設型に比べ情報の収集・交換活動の進んでいる地域専門 型でも2割程度である。また情報に関しても、収集のみの事例がつ ながりをもつ施設の4割以上を占めている。より積極的な連携がま だ進んでいない背景には、普及活動や出版活動と同様、専属職員の 不足など運営体制面での問題が大きく関係していると考えられる。

歴史的建物を生かした博物館施設は、地域の子供たちが郷土の歴 史に興味や関心をもつ上で非常に有効な施設であるが、現実にはく 学校教育と何らかの連携がある>と回答した施設は全体の 3 割程度 であった。比較的多い地域専門型や郷土資料館型の施設でも4割前 後である。大半は小学校社会科授業の一亜としての見学学習である が、教育資料関係の提供（事例 $21.52 ） 、$ 夏休み期間小学生への歴 史等の講座（同19、73）、歴史的建造物の校外学習（同22）、PTA活 動での学習利用（同27）あるいは父母・老人クラブの協力による体 験学習（同54）など、今後の参考になる事例も僅かにみられた。

関連団体を有する施設は 66 事例中 28 例みられた。特に郷土資料館 型と地域専門型に多く、半数の施設で存在する。郷土資料館などで は地域の郷土史研究や資料保存会などが中心となっている。このほ か注目すべき例として、事例 $73^{(216)}$ では小中学生による文化財少年 団「博物館クラブ」が組織され、博物館を扴点に郷土の自然や歷史 の学習、文化財保存保護のための調査活動が行われている。

表10 他の博物馆施設等や学校教育とのつながり、および関連団体の有無

\begin{tabular}{|c|c|c|c|c|c|c|c|}
\hline \multirow{2}{*}{ 施設分類型 } & \multicolumn{4}{|c|}{ 他施設との連携·情報交換等 } & \multirow{2}{*}{$\begin{array}{l}\text { 学校教育 } \\
と の \text { 連携 }\end{array}$} & \multirow{2}{*}{$\begin{array}{c}\text { 関連団体 } \\
\text { あり }\end{array}$} & \multirow{2}{*}{$\begin{array}{l}\text { 事例 } \\
\text { 総数 }\end{array}$} \\
\hline & 連掿 & 情報交換 & 情報収集のみ & (いずれか) & & & \\
\hline 郷土凟料館型 & $3(10)$ & $11(38)$ & $9(30)$ & $20(69)$ & $11(38)$ & $15(52)$ & 29 \\
\hline 地域専門型 & $2(20)$ & $5(50)$ & $3(30)$ & $8(80)$ & $4(40)$ & $5(50)$ & 10 \\
\hline 記念館型 & $2(15)$ & $3(23)$ & $4(31)$ & $7(54)$ & $2(15)$ & $4(31)$ & 13 \\
\hline 文化財型 & $0-$ & $6(43)$ & $3(21)$ & $9(64)$ & $4(29)$ & $4(29)$ & 14 \\
\hline 計 & $7(11)$ & $25(38)$ & $19(29)$ & $44(67)$ & $21(32)$ & $28(42)$ & 66 \\
\hline
\end{tabular}

表注)太数字は事例数を、( )内は事例総数に対寸る比事(名)を示寸。

\section{6. 設置時の建物変更と利用上の建築的問題点}

\section{(1)設置時の建物变更（表11参照）}

修理修復以外特に手を加えず使用している施設は66事例中 21 件 で、約7割は何らかの変更を行っている。特に地域専門型の施設で 多い (10事例中9件)。また文化財型の施設でも、半数の施設で建物 変更がされている。これらの内容は、内部改装 (34例) と設備の附加 (35例) が多く、変更事例の半数に及ぶ。特に、特定テーマの展示や 施設見学者も比較的多い地域専門型施設ではほぼ全てが内部改装と 共に間取変更さらに設備附加を行っている。郷土資料館型も全事例

\section{表11 施設の開設に伴う建物変更等の有無}

\begin{tabular}{|c|c|c|c|c|c|c|c|}
\hline \multirow{2}{*}{ 施設分類型 } & \multirow{2}{*}{ 変更なし } & \multicolumn{5}{|c|}{ 変更あり } & \multirow{2}{*}{ 事例 } \\
\hline & & 增·改築 & 内部改装 & 構造補強 & 間取変更 & 钤備付加 & \\
\hline 郷土盗料館型 & $9(31)$ & $5(17)$ & $16(55)$ & $8(28)$ & $8(28)$ & $17(59)$ & 29 \\
\hline 地域専門型 & $1(10)$ & $3(30)$ & $8(80)$ & $3(30)$ & $8(80)$ & $9(90)$ & 10 \\
\hline 記念館型 & $4(31)$ & $4(31)$ & $7(54)$ & $4(31)$ & $3(23)$ & $5(39)$ & 13 \\
\hline 文化財型 & $7(50)$ & $2(14)$ & $3(21)$ & $3(21)$ & $2(14)$ & $4(29)$ & 14 \\
\hline 計 & $21(32)$ & $14(21)$ & $34(52)$ & $18(27)$ & $21(32)$ & $35(53)$ & 66 \\
\hline
\end{tabular}

\section{表12 施設運営上の建築的制約}

\begin{tabular}{|c|c|c|c|c|c|c|c|}
\hline \multirow{2}{*}{ 施設分類型 } & \multirow{2}{*}{$\begin{array}{l}\text { 何らかの } \\
\text { 制約あり }\end{array}$} & \multicolumn{5}{|c|}{ 制約内容 (不十分な点) 別 } & \multirow{2}{*}{$\begin{array}{l}\text { 事例 } \\
\text { 総数 }\end{array}$} \\
\hline & & a) 設備的 & b) 空間的 & c) 環境的 & d) 20 他 & $a, b, c h す ゙ れ も$ & \\
\hline 鄉士 & $24(83)$ & $10(35)$ & $20(69)$ & $12(41)$ & $2(7)$ & $621)$ & 29 \\
\hline 地域専門型 & $7(70)$ & $4(40)$ & $4(40)$ & $3(30)$ & $1(10)$ & $2(20)$ & 10 \\
\hline 記念館型 & $8(62)$ & $3(23)$ & $5(39)$ & $7(54)$ & $1(8)$ & $3(23)$ & 13 \\
\hline 文化財型 & & & $1(7)$ & $8(57)$ & $2(14)$ & $1(7)$ & 14 \\
\hline 計 & $48(73)$ & $19(29)$ & $30(46)$ & $30(46)$ & $6(9)$ & $12(18)$ & 66 \\
\hline
\end{tabular}

の半数以上が内部改装と間取変更を行っている。一方、旧建物の外 観形態を変えるような增改築の事例は少なく、2割程度である。施 設型別には、地域専門型と記念館型の施設で3割程度と比較的多い。

(2) 建物使用上の制約（表12参照）

歴史的建物の活用による運営上の制約の有無について、設備的・ 空間的・環境的およびその他の 4 つの側面から把握した。その結果、 全体の7割以上の施設で何らかの建築的な不十分さを感じているこ とがわかった。いずれの施設型でも6割以上あり、特に郷土資料館 型施設で多い $(83 \%)$ 。制約の内容としては<空間的に不十分>と 〈環境的に不十分>が多く、全体のほぼ半数近い施設で指摘がみら れた。特に郷土資料館型施設では空間的な制約が7割にも達する。

一方、設備を付加する施設が多いこともあって、<設備的に不十分 $>$ の指摘は全体で約 3 割程度と少ない。

具体的な制約内容の記述でも、空間的制約を指摘したほぼ全ての 事例で「施設の狭さ」を挙けている。展示等のための内部変更では 解決できないスペース的な問題が運営上の大きな制約となって表れ てきている。また、環境的制約では「冬期間の寒さ」が圧倒的に多 く挙げられている(26例)。一方、設備面ではく冷暖房や空調設備 がない＞またはく不十分＞と回答した例は意外と少ない(7例)。活 用されている歴史的建物に木造建築の多いことが、防火上の制約で やむを得ない状況が反映している反面、冬期間の寒さという環境的 な制約につながっている。

施設の維持・管理面で特に苦虑している点として、22件の回答が あった。施設内外の老朽化に対する補修・点検等の配虑、冬期間の 雪害、防火対策に関する指摘が比較的多くみられた。この他、く古 い建物で維持するのに管理費がかかる 增える $><$ 現在作られていない建具等の交換・補修に苦労 $><$ 身障 者に対する便宜が文化財のため難しい>など、維持管理の財政的問 題や補修等の面での技術的問題、施設のバリアフリ一化など、歴史 的建物の活用に関する本質的で重要な問題も指摘されている。

\section{7. まとめ一現状における特徵・問題点と今後の課題}

北海道の歴史的建物を生かした博物館施設の実態について、施設 型別に特徵や問題点をまとめると以下のように整理できる。

\section{表13 歴史的建物の活用事例にみられる主な特徽・問題点}

\begin{tabular}{|c|c|}
\hline 型 & 主な特徵・問題点 \\
\hline $\begin{array}{l}\text { 哏 } \\
\text { 算 } \\
\text { 料 } \\
\text { 館 } \\
\text { 型 }\end{array}$ & $\begin{array}{l}\text { ·施設規模に比して職員数が少ない。 } \\
\text { ·開館日数む少なく、冬期閉館が多い。 } \\
\text { •自治体所有であった建物が比較的多い。 } \\
\text { •設遗に際して住民からの要望が奇せられたことが多い。 } \\
\text { •地域との密着性が比較的高い。 } \\
\text { •現状の建物では規模的に不十分。 } \\
\text { ·建物の更新がみられ、施設機能の移転の可能性もある。 }\end{array}$ \\
\hline $\begin{array}{l}\text { 地 } \\
\text { 䍏 } \\
\text { 閏 } \\
\text { 型 }\end{array}$ & 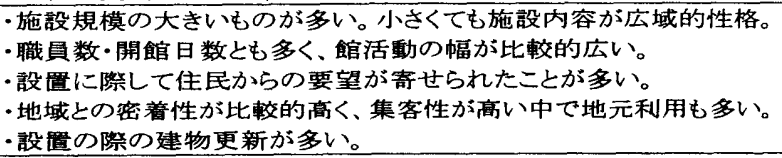 \\
\hline 記 & 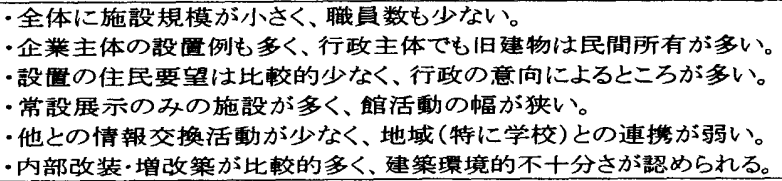 \\
\hline $\begin{array}{l}\text { 文 } \\
\text { 化 } \\
\text { 椇 } \\
\text { 型 }\end{array}$ & 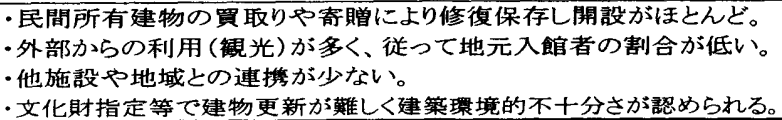 \\
\hline
\end{tabular}


以下に、北海道における博物館施設への保存活用事例の実態分析 結果をふまえた、今後の課題について考察しまとめる。

1)一口に博物館施設といっても一様ではなく、施設の種類によっ て問題点にも違いが見られる。記念館型や文化財型は、建物の由来 や価値を率直に表現しているが、地元住民との密着性が比較的希薄 で、周辺との慗がりを強化し、建物の価值を活かした有機的活動を もっと推進すべきと思われる。博物館のタイプとして最も多い郷土 資料館型は、地域の郷土学習の主要な拠点施設として開館日数、職 員数など運営体制の向上が今後の課題としてあろう。

2) 建物が手狭との指摘が郷土資料館型に多くみられたが、社会教 育的な要望への対応を急ぐあまり安易な移転、取り壊しは考えずに、 建物の洒值を尊重した上での機能分配、それによる生涯学習活動等 も含めた多様な活用を図っていくことが望まれる。これは施設リニ ューアルが多くみられた地域専門型施設にもいえることである。

3) 歴史的建物を活用した博物館施設の多くは、〈建物を残し生か すこと＞と＜施設設置＞に対する地域住民の要望もあって実現して いる。しかし出来上がった施設に対する期待は、建物の歴史的役割 については比較的高いものがあるが、まちのシンボル的な存在とし ての認識は全体に低い状況にある。こうした背景には、施設入館者 の少なさや地域との連携の弱さなども大きく影響していると思われ る。歴史的建物あるいはその存在する場所のもつ意味を生かした多 様な活動の可能性を検討し実行していくこと、そのためには地元住 民を中心とした支援活動団体等の結成を促進し、学校教育とも密接 な連携を積極的には図っていくこと、また施設活動や地域との連携 を通じて住民へ継続的なアピールをしていくことが必要であろう。

4) 冬期休館の施設では、今後、活用できる期間中に如何に有効か つ意義多く施設・建物を生かし得るかの知恵や工夫が求められる。

5) 歴史的建物は、その外観だけでなく内部空間も併せて建築的な 意味が伝えられる。博物館施設としての展示機能の確保のため建物 内部に手が加えられることはやむ得ないことかもしれない。しかし、 それは最小限にとどめるような活用の工夫も求められよう。また、 旧状がほとんど同えない程に変更せざるをえない場合でも、建物の 生い立ちやくかってどのように使われていたか＞などを見学する人 々に伝える工夫もされるべきであろう。

6)一方、歴史的建物を活用することで施設的な制約や不十分さを 感じる施設が非常に多くみられた。その背景には、せっかくの郷土 の博物館・資料館ということで施設的に多くを求めすぎていること も一因として考えられる。利活用する建物の内容や規模に応じた活 用再生、さらには複数の施設や新設の建物を附加、といった柔軟な 検討も必要であろう。

本報告では、歴史的建物の博物館施設への保存活用実態について、 全道的な事例把握とそれらの経緯や背景および施設建物の主に運営 ・管理等の面から検討した。さらに、博物館施設の機能的側面から の詳細な実態やそれぞれの地域のまちづくりとの関わり等も含め、 より総合的に検討していく必要がある。今後の課題としたい。

最後に、アンケート調査に御協力を頂いた各市町村の関係各位、 ならびに調査およびデー夕整理に協力を得た当研究室卒業生の山下 昌彦君に対し感謝の意を表します。
注記

注1)文2)では、1983年刊行の日本建築学会編『新版・日本近代建築総臨』に 記載の再利用建物のうち、現用途別件数で「資料館・博物館建築」が最も 多い $(17 \%)$ ことが分析されている。また、自治省のふるさと資源調查結 果视 でも、資源転用後の種類として「資料館等」が全事例の約 $27 \%$ と最も 多いことが報告されている。

注2) 文部省の社会教育調查 (1990.10.1現在)よると、道内の博物館は196（登 録施設・博物館相当施設 49 、その他の類似施設 147）で、都道府県別には長 野県（205）に次いで多い文5)。また、北海道博物館協会の発表（1986.3） によると、1985年現在で博物館園数は284で、その数も「完全なものではな く、その総数は300に近くなるものと推察される」としている対。

注3) 北海道新長期総合計画（1988〜97年度）の戦略プロジェクトの一つ。

注4) 重要文化財·旧偕行社を活用した中原俤二郎記念·旭川彫刻美術館など。

注5)市立函館博物館先住民俗館・水産館、北海道大学農学部付属博物館など。

注6) 社会教育課、生涯教育課、または文化財課など。

注7)対象事例の把握については、その後の新しい文献資料吝い゙による検索お よび市町村関係部局への補足ヒアリングを行ったが、新らたな施設は確証 されなかった。

注8)アンケート調查結果の概要については、本報に先立って、日本建築学会 北海道支部の研究発表会で報告した文14

注9）文11) および文12）には美術館や科学館、動物園、水族館、植物園等を除 く博物館施設が244例紹介されているが、この中には本報の対象事例が46件 みられた。今回の調查では、このほかに新らたに 39 施設が把握された。

注 10) 歴史的建物活用の博物館施設の北海道最初の例は、1956年に「日本郵船 小樽支店」を活用して開設された小樽博物館 (現施設の前身)である。同館 は、その後1985年に「小樽倉庫 (株) 倉庫了を再利用し現在に至っている。旧 建物はその後も、文化財型の博物館施設 (表1中の事例33) として現存する。 注11) 住宅系の建物のほとんどは、番屋建築や駅进所·通行屋、軍の官邸など 特殊な建物である。

注 12$)$ 文部省の社会教育調查 (1990年度)によると文5)、博物館類似施設も含め た道内の博物館のうち登録・相当施設の割合は $25 \%$ 之、全国平均 $(27 \%)$ よ りも若干低い。

注 13) 事例 34 : ふるさとづくり事業、同59:地域総合整備事業、同 80 :まちづく り特別対策対策事業、の3例。

注 14) 設問（重複選択形式）は、(1)施設がまちのシンボル的存在となっている かあるいはなりうる、(2)建物のもつ歴史の証人としての役割、(3)その他。

注15) 事例56 (上富良野町郷土館) では、1981年から毎年『哏土を探る』を蚱土 館協力団体 (上富良野町郷土をさぐる会) によって発行が続けられている。

注 16) 浦河町瓦土博物館 (登録博物館)。同館の創設は戦後道内の博物館の中 では古い(1961年)。博物館友の会も結成されており、館活動も活発である。 また創設時も歴史的建物 (旧赤心社事務所) を活用しており、北海道では旧 小澊博物館 (注7)）に次いで早い時期の歴史的建物活用型の博物館である。

\section{参考文献}

文1) 三船康道＋まちづくりコラボレーション：まちづくりキーワード事典, 学芸出版社, 1997.3

文2) 時野谷茂・西沢泰彦: 近代建築の再利用例に関する研究 (1)，日本建築 学会大会学術梗概集 F (関東), 1984, pp. 2675-2676

文3) 自治大臣官房政策室監修・(財) 地域活性化センタ一綟 : 再発見！！ふる さと資源 \&ランドマーク，(株)ぎょうせい, 1990.11

文4) 工藤欣弥: “博物館王国”を考える, 『北海道を探る17く北海道の活性 化を求めて・その 1>』，北海道みんぞく文化研究会，1988

文5) 関秀夫:日本博物館学入門, 雄山閣出版社, 1993.3

文6)石本正明·督沼秀樹·越野武·角幸博ほか：北海道における歴史的資産を 活かしたまちづくりの展開に関する研究一各市町村の取り組みと住民意識 の実態, 北海道都市学会, 都市学研究 No34, pp. 25-34, 1997. 12

文7) 星野貴·越野武·角幸博 : 札幌における歴史的建物の再利用一その現状と 使用者の意識一, 日本建築学会北海道支部研究報告集N 067, pp. 541-544, 1994. 3

文8) 江下友三枝·越野武·角幸博 : 小樽における歴史的建物の再利用一その現 状と使用者の意識, 同上No67, pp. 545-548, 1994. 3

文9) 村國健·越野武·角幸博·石本正明ほか：函館における歴史的建造物の再 利用について, 同上№72, pp. 525-528, 1999.3

文10)确口章·越野武·角幸博ほか：北海道公立小中学校旧校舎の保存活用の 実態について，同No66，pp. 405-408, 1993.3

文11) 北海道博物館協会編: 北海道博物館カイド, 北海道新聞社, 1991.5 文12) 宮内令子 : 北の博物館, 北海夕イムス社, 1991. 6

文13北海道博物館協会編: 北海道・新博物館ガイド, 北海道新聞社, 1999.7 文14）山下昌彦·越野武·角幸博·石本正明 : 道内歴史的建造物の資料館施設へ の保存利用に関する研究, 日本建築学会北海道支部研究報告集 No70, pp. $641-644,1997.3$ 。

文15) 柳瀬源太郎：博物館学網要, 理想社, 1950、など。

文16) 野村東太ほか：全国博物館の運営・施設の一般的状況一博物館に関する 建築計画的研究 (1)，日本建築学会計画系論文報告集No. 353，1986. 4

[2000年 4 月17日原稿受理 2000年 7 月26日採用決定］ 